\section{ONE YEAR OF INTERSTATE COMMERCE CONTROL.- WHO IS THE GAINER?}

JUST one year ago the government laid the iron hand of a Bismarck upon the railways of this nation, their procedure, tariffs, and particulars, under guise and pretext of a provision of the Constitution, framed at a time when railways were unconceived of in the brain of man, and when the only possible object of that provision must have been to prevent internecine commercial hostilities or discriminations among the States. Who has been benefited? The best evidence attainable ought to be the statement of the commission appointed to administer the statute taking control of the railways. In this first annual report the commission says (the Italics are ours), "The Act to regulate commerce has now been in operation nearly eight months. . . . It has operated clirectly to increase railroad earnings, especially in the cutting-off of free passes on interstate passenger traffic. . . . Freight traffic has been exceptionally large in volume, . . . no destructive rate wars have occurred, but increased stability in rates has tended in the direction of stability in general business." In other words, then, it is the railway companies which have been benefited.

But this was not the object of the statute. The railways had not complained of ill treatment. They had, indeed, recognized the immense complications of competing systems, the damage suffered by the people from the rate wars and unjust recoupments for the expenses thereof, and had themselves provided a remedy by the establishment of so-called ' pools;' which, however, the Act of Interstate Commerce promptly and peremptorily abolished. It is something of a commentary on the words we have put in Italics above, that whereas, at the date at which the statute took effect, the situation was tranquil and satisfactory (the 'pools' having lowered rates to a minimum never reached before), the passage of the Act sent tariffs upward at a bound; and before the report above quoted had left the binder's hands, a rate war began in the West whose bitterness has, so far, surpassed in violence any ever known. At this writing the companies engaged have lost, and are daily losing, millions, until several of the roads involved have ceased to solicit freights, because to do no business is cheaper than to move their trains for unprofitable transportation. And it will not fail to add comment to commentary, that while this very Interstate Commission has been sitting calmly at Washington, dismissing trivial complaints against great trunk-railway systems, the ironclad statute which creates it forbids these very warring railways from warding off bankruptcy by coming together, pooling their issues, and terminating the battle which is sapping their resources. Next July the semi-annual dividends will be found adjusted to this rate war, and so the people of the United States will pay all the bills; and the railways, relieved of their burdens, can go on again. But such relief will clearly only be temporary as to them, with the prospect of more wars and more bills for the people to pay. Meanwhile the statute of interstate commerce continues to centralize without adjusting, or attempting to adjust, the larger problems, while carefully hearing and writing opinions as to the least of minor and local particulars of which individuals believe themselves warranted to complain; and this, although the statute itself expressly empowers the commission to take jurisdiction of its own motion, and in the ab. sence of any actual complaint whatever (on grounds of public policy, no doubt ; but, upon whatever policy, an opportunity just now very carefully overlooked by this honorable commission).

By the time this paper appears in print, the warring railroad companies will probably have come together in 'conference,' ' committee,' or 'synod,' and terminated the ruinous battle I have above alluded to. Only (in deference to the statutes of united Germany, and the Bismarck policy whose spirit has materialized among us in the shape of an interstate commerce law), whatever they call it, they will be mighty careful not to call it a "pool.'

But why should the interstate commerce statute be operated to favor the railroads? Such were not the reforms sought. The Interstate Commerce Act was the concentration of popular forces, which had for years fought railway incorporations in our legislatures and in our courts: the crystallized expression of fifty years of popular discontent with railway management throughout this Republic. The people looked to the first utterance of a commission created to administer it, for arraignment of the wrecked railways for their disregard of popular rights, their high-handed indifference to law, and their supercilious contempt for the non-railway element in the community, that should be scathing in its terms, and triumphant in its justification of the government's constitutional right to assume control of a private interest, and to take the first step toward that centralization which Washington deprecated in prospect, which Jackson scotched in its birth, and from the possibility of which a bloody and costly civil war was supposed to have finally relieved. Nor was it mere aimless legislation. The experiment of biennial or even triennial legislatures in some of the States, as tending to decrease the volume of legislation, has always been found to work well The volumes of session laws of our States are, as to their bulk, apt to become mostly lumber in a surprisingly short time, the number of statutes whose usefulness will survive the first few years of their passage being found a surprisingly small one. And even of our National Legislature it can be fairly said that the more time it wastes, the greater the nation's gain. But the interstate commerce law was no product of mere zeal, or temptation to legislate on general principles. It was the offshoot of sentimental prejudice and jealousy, no doubt ; but its fathers and advocates in Congress cannot be suspected of having been actuated by either motive. The vastness of the nation's growth for half a century had rapidly made railroads into systems. The immensity of the plants, the accumulation of costly rolling stock, the huge volume of business, could not fail to impress the people with a sense of power not proceeding, like the power of the government, from the consent of the governed from themselves. The enormous operations carried on daily in the people's eyes suggested enormous profits, and engendered popular discontent. These enormous operations necessitated new channels and feeders ; that is to say, new railways. To save time, the ingenuity of the nineteenth century had devised construction companies, which, by subscribing for the capital of these new roads, should obviate the slow and tortuous collection of money by private solicitation ; and these, centralizing profits as well as subscriptions, massed wealth in localities, and attracted the popular envy. The boundlessness of all these brought great bankruptcies for courts to deal with; and the result of each was the inevitable wrecking of great corporations, and the private accumulation of wealth in the hands of the winners in these legal fights. No sooner was this the situation than a new problem intruded itself upon the already complicated maelstrom. The movement known in Europe inclifferently as internationalism, socialism, or nihilism (where it grew originally from the discontent of the constantly enlightening and self-educating masses at the support in opulant idleness of privileged classes, useless courts, and - to the people - always absolute monarchies) was utilized to express among us the popular envy, discontent, and prejudice against corporations it felt in Europe only against kings ; and the result was felt in strikes, trade-combinations, and central labor unions, where one trade supported another, and each all, in abandoning work by the thousands and ten thousands at one and the same time. Underlying all this was, of course, the capital fact that the railway industry itself was not at fault; was not responsible for the shrewdness of the Wall Street operator: for intentional defaults in dividends and interest procured for wrecking purposes: for the huge competition and the closeness of margins which put them at the mercy of a single disastrous season. The president of a great railway recently asserted, in answer to a demand from the company's employees for higher wages, that in twelve years his company had not only not netted a dollar, but had actually mined and distributed $5 \mathrm{I}, 000,000$ tons of coal at a cost of $\$ 5 \mathrm{I}, 000,000$, and paicl $\$ 53,000,000$ for the privilege! The margin of profit had disappeared entirely in the giant competition of American railway companies, which yet had given, and was daily giving, support to almost a tenth part of the people of the United States.

But great economic facts like these, like great investments, lose strength by their very immensity. The laborer working ten hours a day, six days in the week, with a family of ten children clamoring for food, cannot be approached with figures showing, that, out of a hundred millions of income, his employer had not been able to reserve one ten-thousandth per cent; that the private fortune amassed by one man in railway wrecking was the crystallization of ruinous losses to thousands of smaller capitalists not of the working-men; that the plant of the great corporations had been paid for by the 
hard-earned savings and small economies of thousands more; and, most of all, that, of the total of all these losses and savings, almost a hundred per cent had gone to pay for labor, and for material the cost of which itself was largely the labor of handling it. Such statements as these, few of his betters have the brains to grapple with. The day-laborer may have sundry vague impressions that he should be paid in proportion to the number of his children rather than according to the value of his services; that the idea of anybody handling a million of money is a personal affront; and that altogether he is a slave, and that any change and convulsion, and shifting of bases, could not make him more wretched, and brought an even chance of betterment. He may not even be equal to these ideas, but simply absorb the single idea that the master of his local union has money to occasionally pay him a per diem almost as great for not working as he receives from his employer for working. But he knows that he is the slave of somebody. The nearest railway company is to him the most prominent representation of massed wealth, and he accordingly selects it for the slavedriver against whom he is to rebel. Everybody saw the wrong, but the remedy was not so apparent. Everybody sees logically that the railway as an institution is innocent of all this chaos. But logic is one thing, and practical solution, quelling of clamor, amelioration of disasters, are quite another. So it was that when the complicated problem reached the floor of Congress, it was no longer a sentiment, a prejudice, or a jealousy : it was a mighty and imperious fact, demanding and insisting upon immediate attention. Congress passed the Act to regulate interstate commerce, the President approved it, and it was the law of the land. It has been in operation a year. So far as the people of these United States are concerned, has it changed the situation (existing at its approval, and admittedly clamoring for remedy) in the slightest degree? Have strikes ceased? Are rates lower? Have private fortunes disappeared or ceased to be accumulated? Have the railways been curtailed in their despotic sway over the lives, fortunes, and liberties of our people? Had any recipient of a pass over one of our railways, or of a drawback, rebate, or special privilege, complained to Congress that he had been so favored? (That concessions to the few were injuries to the many, and the 'pass' system an unmitigated wrong and nuisance, - these were the complaints of the railway companies, not of the people; and Congress had heard them with ears as deaf as adders' ears for the last quarter of a century.) To these questions some of us are still looking for an answer, others the commission itself has answered for us. The Interstate Commerce Commission (to its credit everlastingly, be it said) did not wait for the filing of its first annual report to come boldly forward and tell the people of the United States that they were in error; that the railways were not their enemies; that, although bound to assume that it had been created for some wise purpose, and therefore to hunt around to find that purpose, the commission did not propose to share in the communistic cry of 'Down with the railway's!' or even to adinit that railways were a menace to the liberties of the people. It seized upon its first opportunity to assume that the statute of interstate commerce was of no practical value to anybody, but intended to be understood in a purely Pickwickian sense.

That opportunity was the presentation of a petition, on the part of one of the corporations to be brought under the paternal power of the commission, - the Louisville and Nashville Railroad Company, - for relief from the operation of so much of the fourth section of the Act as prohibited railway companies from charging more for the 'short haul' than the 'long haul,' - a prohibition which was and is the gist of the Interstate Commerce Act, and which opens up the entire question of the right of a railway company to judge for itself as to its right to live, operate its roadway, to pay its fixed charges, or generally to conduct the business for which the people had incorporated it. For to say that a grocer may sell sugar, but that if another grocer across the way also sell sugar the first grocer may not compete with the second grocer, is clearly to so embargo the first grocer as to close him out. To be sure, the law added a clause limiting the prohibition to " substantially similar circumstances and conditions;" but the limitation scarcely helped matters, since it merely substituted a question of fact for a question of law, and opened an interminable and costly field for the taking of testimony and the examination of witnesses which could easily paralyze any interest forced to enter it. Besides, to recur to the simile of the grocer, it might be said to permit the retail trade in sugar only on condition that no wholesaling was attempted. He might sell a pound of sugar at any price he could get, but must be careful, if he sold a thousand hogsheacls, not to diminish his rate per pound, either by quoting his commodity at less, or by rebating or offsetting for the comparative magnitude of the transaction. Such, then, being the opportunity, the cause of the client, the opinion of the commission in this first case of importance was looked for as an emphatic justification of the law the people had enacted.

But on being promulgated, the opinion, so far as any crimination of the railway companies or any indication of the constitutionality or policy of the law was concerned, turned out to be as unsatisfactory to the non-railway public as Balaam's cursing of Israel was to Balak. "What hast thou done unto me?" cried the disappointed king. "I took thee to curse mine enemies, and, behold, thou hast blessed them altogether." The first pronouncement of the Interstate Commerce Commission begins with an apology for not interfering with the railway companies, which, to say the least, was unique in juridicial literature. It declared (p. $5^{1}$ ), that, " if the commission were to perform the inquisitorial duties imposed upon it, it would be compelled to forego the performance of judicial and other functions which by the statute were apparently assumed to be of high importance, and even then its authority to grant relief would be performed under such circumstances of embarrassment and delay that it must in a large measure fail to accomplish the beneficial purposes which it must suppose the statute had in view." The commission deprecated any performance under its inquisitorial function, since that function " in a single case might require for its proper determination the taking of evidence all the way from the Pacific to the Atlantic; and this not merely the evidence of witnesses for the petitioning carrier, but of such other parties as might conceive that their interests or the interest of the public would be subserved either by granting the relief applied for, or denying it" (p. 5). Certainly, nobody can blame the commission for preferring to sit cosily in Washington and exercise judicial functions than to take testimony not only of the parties before the commission, but of any party who might consider himself aggrieved by any act of a railway company or by any proximate or remote effect of such act or its theory, from Maine to California. And, even should the commission be able to decide the matter before it without the bother of hearing testimony, the commission admits that "an adjudication upon a petition for relief would in many cases be far from concluding the labors of the commission in respect to the equities involved: for questions of rates assume new forms, and may require to be met differently from day to day: and in those sections of the country in which the reasons or supposed reasons for exceptional rates are most prevalent, the commission would, in effect, be required to act as rate-makers for all the roads, and compelled to adjust the tariffs so as to meet the exigencies of business while at the same time endeavoring to protect relative rights and equities of rival carriers and rival localities." "This [and here is a touch of nature which shows, at any rate, that an interstate commissioner's life threatened at the very outset to be no bed of roses] in any considerable state would be an enormous task. In a country so large as ours, and with so vast a mileage, it would be superhuman. A construction of the statute which should require its performance would render the due administration of the law altogether impracticable" (p. 5) says the commission finally. And yet, if the Interstate Commerce Act means any thing, it means just what the commissioners, in their first decision, declared to be impracticable, - superhuman and impracticable! Here are seven commissioners, at a salary of seven thousand five hundred dollars per annum, launched with an appropriation of one hundred thousand dollars from the people's treasury, and on that equipment expected to supervise the hourly business of a continent at present in the hands of perhaps a couple of thousand auditors, with a combined staff of a hundred thousand clerks and agents - with salaries ranging from twenty thousand dollars downwards, and overworked at that ! But to proceed with examination of the opinion. Having frankly admitted that to endeavor to discharge the functions it was organ-

1 The references are to the official copy of the opinion printed at the Government Printing-Office, Washington, 1887 . 
ized to administer would be superhuman and an impossible task, the commission sets to work, as in duty bound, to find something to do. It is legally bound to assume that it was created for a possible purpose, to do something not superhuman. And so the commission, groping, as it frankly admits, in the dark, strikes at last upon the cause, "under substantially similar circumstances and conditions," and finds at last a foothold. Surely, it says, "if the carrier ... shall depart from the general rule, . . . if the circumstances and conditions of the two hauls are dissimilar, the statute is not violated." Clearly, if Congress shall take the grocery trade under its jurisdiction, and declare that the poor man must not be obliged to pay more per pound for his two pounds of sugar than the dealer pays per pound for his two thousand hogsheads, it would put an end to the wholesale grocery business on the instant. But if Congress says that this rule shall only apply to the sugar made " under substantially similar circumstances and conditions," then the sugar trade may go on in peace, as before, relying on the immutable truth that no like transactions are or can be under the same circumstances and conditions, and foregoing to attempt the 'superhuman task' of taking evidence all over the continent, from the planters, the cultivators, the harvesters of the sugar-crop, the teamsters who carried it to the railroad, the shipper, the booking clerk, the carrying company, and so forth and so on, down through the jobber, the wholesaler, to the consumer or the messenger sent to pay the twenty or twenty-five cents for the brown paper parcel, - in perfect faith that in no two cases can the adjective clause 'substantially similar' be predicated to any one transaction when collated with any other transaction on record. Certainly the commission is right. Indeed, the wonderful part of the opinion is in the exact legal consistency and canclor with which it admits that the law is one, which, if logical, is impossible of enforcement: and, if illogical, can only be administered by leaving matters precisely as they were before the law was passed! Following the above line of reasoning, the commission declares (p. 6) that the statute becomes practical, and may be enforced without serious embarrassment. The commission, having settled this much, now proceeds to collate the two sections of the Act which relate to the long and short haul (Sections 2 and 4), and proceeds, "It is not at all likely that Congress would deliberately in the same act, and when dealing with the same general subject, make use of a phrase which was not only carefully chosen and peculiar, but also controlling, in such different senses that its effect as used in one place upon the conduct of the parties who were to be regulated and controlled by it would be essentially different from what it was as used in another" (p. 7). And therefore the commission renders its decision in a sentence which I must be pardoned for putting in Italics: "Beyond question, the carrier must judge for itself what are the substantially similar circumstances and conditions . . on peril of the consequences" (p. 7). But is not this what every carrier (nay, every business-man) does, has always done, and always will do to the end of time? And is not this a pronouncement from the mouth of the Interstate Commission itself, that if the clause "under substantially similar circumstances and conditions' is of the essence of the Act, then the law is a nullity?

But after having arrived, by application of every rule of law, and the legal construction of statutes, - that is to say, by irresistible logic, - to its conclusion on p. 7, the commission proceeds for twenty-two pages more to discuss analytically and still logically the situation. What situation? The case submitted by the petition, the Louisville and Nashville Railway Company, was simply the case which arises every moment of the day to any railroad company which carries freight for hire; and while considerable percentage of these cases are not necessarily 'interstate' in their character, yet every practical ralload man (certainly every student of political economy) knows that such a character, from a commercial standpoint, could be given to almost every one of them without any difficulty. The remaining twenty-two pages of this startling opinion - startling in that it is a confession at the outset that the Interstate Commerce Act cannot change the situation without discontinuing the business and commercial transactions of the people of the United States - is merely an analytical examination of the reciprocal relations which arise between a shipper and a carrier in any contract of transportation.
The commission proceeds to lay down the following propositions, which it deduces from the case before it, and the evidence taken:-

"Ist, That the support and maintenance of a railroad ought properly to be borne by the local traffic for which it is supposed to be built, and the through traffic may justly be carried for any sum not below the cost of its own transportation.

" $2 \mathrm{~d}$, That the cost of local traffic is greatest, and the charges for carrying it should be in proportion; and, if they are so, they will often result in the greater charge for the shorter haul.

" $3 \mathrm{~d}$, That traffic carried long distances will much of it become impossible if charged rates corresponding to those which may properly be imposed on local traffic; and it must therefore be taken in recognition of the principle accepted the world over, that the traffic must be charged only what it will bear.

" 4 th, That the long hauls at low rates tend to build up manufactures and other industries without injury to the traffic upon which rates are heaviest.

" 5 th, That charges on long hauls which are less than the charges on shorter hauls over the same line, in the same direction, are commonly charges which the carriers do not voluntarily fix, but which are forced upon them by a competition from whose compulsion there is practically no escape."

Since the above propositions are axioms in railway management, and since, however immutable, axiomatic, and eternal they are--were before there was any Interstate Commerce Act or Interstate Commerce Commission, and will be after both have been numbered among the figments of the past; since the commission is not supposed to be organized for the purpose of ruling that black is black, and white is white, - what was left for the commission to say to the railroads of the United States except, "Depart in peace, be ye warmed and filled, you have done nothing worthy of death or of bonds, you have conserved the best interests of the people, have built up a continent, and are worthy of the highest praise"? That is precisely what it does say, for it unhesitatingly adds, "On the construction we give to the statute, these several applications need not have been filed, and therefore they might now be withdrawn without further judgment ' (p. 8). But the commission remembered the Act upon which it was created, and that it was expected to justify at least the action of Congress in creating it, and so announced its willingness to go into the merits of the question (it had just decided that there was no question), making its excuse, "that it is manifestly important to the public interest, as well as to that of the railways themselves, that mistakes shall be as far as possible avoided" (p. 9), (a proposition to which certainly nobody can demur); or to limit these propositions, or discover anywhere a public need or benefit that the management of the railways of the country have overlooked. How should the situation be changed to benefit the people? How can it be changed without destroying our interstate commerce; nay, without destroying the welfare of the country and paralyzing all business transactions? "Every railroad company," says the commission, "ought, when it is practicable, so to arrange its tariffs that the burden upon freights shall be proportionate on all portions of its lines, with a view to revenue sufficient to meet all the items of current expense, including the cost of keeping up the road, buildings, and equipment, and of returning a fair profit to owners." But this is precisely what every railroad does, has always done, and always will do. To attempt to make tariffs other than proportionate would require an increasing of its book-keeping expenses, and of its auditing bureaus, to every railroad company, which would make it cheaper to go out of the business than to continue. In other words (the words of the opinion), "a railroad ought not to neglect any traffic of a kind that will increase its receipts more than its expenses" (p. 22). To state it frankly, therefore, the opinion of the commission, in the case of the Louisville and Nashville Railroad Company, is a benign approval of the business methods of our railroad companies which certainly merits the exclamation of King Barak over the efforts of the prophet Balaam.

And then the commission repeats in detail its already general commendation of the railways of this Republic. It says that they may compete with Canadian railways (p. 22) and with the watercourses (p. 22). And the commission therefore arrives at its rulings 
(p. 27), which (except that it interprets the short and long haul clause to mean that a question of fact is thereby substituted for a question of law; and, inferentially, that to determine it the testimony of every individual in the employment of the railway must be taken by the court) does not in the slightest degree change the habitude and method of running a railway; does not introduce a single innovation, or modify a single rule of railway operation : in other words, Congress has enacted a statute which a commission chartered to enforce it declares enacts that things shall remain as they are, and that, if the statute is ever suspected of interfering with things as they are already, the subjects of the statute must interpret it blindly and at their own peril!

It would seem, therefore, that the commission itself has decided that the railways of this Republic have been, up to the date of its own appointment, properly managed: certainly there is no disapproval of any particular acts, and only in the sixth ruling cloes it condemn certain possible acts and differentiations which it is not alleged that any railways have been guilty of, and which certainly, therefore, is mere obita, or the expression of a general opinion upon a very interesting but entirely gratuitous conundrum of supposititious railway policy. But is not a disturbance of constitutional limitations a rather high price to pay, even for so valuable a boon as is a governmental approval of American railway management? Once broken, who can say what will pass these barriers? Perhaps there may yet be established at Washington an interstate theatrical commission which shall review and absorb the early functions of Master of the Revels, stage censor, and Lord Chamberlain! And, indeed, for such a bill, congress need not again borrow its policy from an Empire of Blood and Iron. It can get its suggestion this time from a Republic - from Mexico - where theatres are not only under the espionage of government, but even the migratory Yankee circus is officially coerced into living up to its posters.

APPLETON MORGAN.

\section{MENTAL SCIENCE.}

\section{Morbid States of the Attention.'}

THE absence of attention is usually termed 'distraction,' but there are really two kinds of lack of attention. In the first there is a constant flitting of the mind from one idea to another, a constant dissipation of the energies in all directions, for which the word 'distraction' may be retained; and there is the lack of attention to the impressions going on about us, due to the fact that the attention is really absorbed in something else, - this is absent-mindedness, which is thus an extreme 'present-mindedness' to a different train of thought, and may be termed 'abstraction.' It is with the exaggeration of one or other of these two conditions that morbid states of the attention are allied. If we take as a convenient definition of normal attention, 'a temporary predominance of a mental state with a natural or artificial adaptation of the subject,' then we can distinguish two groups of morbid deviations:(I) an absolute predominance of such a state that becomes fixed and cannot be dislodged from consciousness; and (2) a state in which no idea can get an audience, and the attention is too weak to hold an impression steadily in the mind. To this may be added a third group, in which, through congenital defect, the power of attention never develops, as in idiots and the weak-minded.

There are all degrees of transition, from a normal concentration of the attention to the most imperative forms of fixed ideas. We have all been haunted by an aria which we cannot stop humming; have been anxious about a sick friend, so that in spite of ourselves we could think of nothing else. This is a mild form of possession by an idea, that is more persistent than any other, keeps itself in consciousness, and by imperceptible steps passes beyond the control of the will. The profound absorptions of many great men in their work are so much beyond their own control that one cannot but recognize an element of the morbid in them. When the object of reflection is a less worthy one, and the devotion to it, far from coinciding with the intentions of the individual, seems to him as an imposed task, we speak of an insistent idea (zwangsvorstellung of the Germans). M. Ribot distinguishes three kinds of such, accord-

1 Abstract of an article by Th. Ribot (Rezue Philosophique, February, r888). See Science, Dec. 2 and 16,1887 . ing as the purely intellectual, the emotional (usually a fear, as the long list of phobias indicates), or the voluntary (usually a morbid impulse to an absurd or criminal act, kleptomania, etc.) predominates. The first class is the most important in this connection. The insistent idea takes many shapes, and in most of these we can trace analogies to our own every-day experiences. There is an arithmetical form of it, that sets the patient to ask, Why are men just so and so high? Why have houses this particular height? and so on. Again : it may be a mania for counting every thing, the number of pavements on a street, the number of streets in a city. The sight of a bag of grain irresistibly led one patient to estimate how many grains there are in the bag, how many in the country, etc. Another must count all the trains leaving the railroad-station, and keep account of their destinations. In these cases the patients often recognize the morbid nature of their thoughts: they fight against them, know that they are wasting time; but the ideas fill their minds completely, and demand attention with a tyrant's power. A feeling of intense discomfort, of an impending evil if they fail to count the trains, etc., is sometimes associated with the state. There is, too, a metaphysical mania, in which the mincl busies itself with unanswerable questions as to the constitution of matter, the final ends of nature, and so on. Persons. thus affected are usually of more than average culture; for the concentration of attention implies mental power. Nor are the objects of their thoughts entirely different from ours: the main difference is in the time and the control of these states. We think of such problems for a while, and then pass on to something else: to them that is impossible. In other respects such patients are often perfectly sound, and show great ingenuity in concealing a knowledge of their weakness from their associates. In general, it can be said that a large proportion of persons thus afflicted are the offspring of neuropathic parents, and not infrequently show other and physical symptoms of a degenerate stock. But the environment, education, must be called into account to explain others of them; and each case, especially as regards the particular form that the idea takes, must be studied by itself. The state differs from the normal, then, in degree rather than in kind. It is persistent, it is intense, it allows no relapse to a diffuse condition of the attention, and, as a mark of nervous disorder, it carries with it a weakness of the will that cannot drive out the unwelcome and officious visitor.

A more intense and acute concentration of the attention is to be found in the trance state, or ecstasy. This is allied to contemplation, to absorption in intellectual work, and brings with it an insensibility to outward impressions. When the state is very profound, such impressions can be intense and yet pass unnoticed. Archimedes, during the taking of Syracuse, remains absorbed in his contemplations. Soldiers often do not know they are wounded until the fight is over. Here, again, there is a high degree of mental power necessary, though it is often exhibited by fanatics otherwise mentally inert. But M. Ribot properly distinguishes between the cases in which the object of the contemplation is a sensory one and those in which it is purely ideal, and adds that the fanatics usually display the former kind of extreme attention. As a type of the more spiritual kind of ecstasy, the remarkable confessions of St. Theresa (a Spanish religionist of the sixteenth century) is cited. She describes no less than seven stages of ecstasy which are in a rough way capable of a psychological interpretation. The first is a state of 'vocal prayer ;' that is, the praying in a loud voice draws the attention away from the outside world. The second stage is termed 'mental prayer.' The sensory impressions are no longer necessary, the mind being held by the ideas that fill it. The 'prayer of meditation' marks the third stage, which is perhaps only a more intense form of the previous state. The fourth degree is characterized by the 'prayer of passivity.' 'Here the soul no longer produces, but receives, has truth directly impressed upon it without the need of a logical demonstration. The fifth stage, the "prayer of union,' marks the beginning of the ecstasy, but it is as yet an instable state, and the possession is not profound. Finally, in the sixth stage, the 'prayer of rapture,' the body becomes cold, speech and respiration are checked, the eyes are closed, the slightest. movements require great effort, and in rare cases consciousness is lost. The seventh clegree of ecstasy is very mystically described. 